\title{
TOURIST CONSUMPTION OF A CONTEMPORARY CITY - A TRANSGENERATIONAL ANALYSIS
}

\author{
JOANNA KOWALCZYK-ANIOŁ, ${ }^{1}$ MAREK NOWACKI ${ }^{2}$ \\ 1 University of Łódź \\ Faculty of Geographical Sciences \\ Institute of Urban Geography and Tourism Studies; \\ CiTUR Centre for Tourism Research, Development and Innovation, Portugal \\ e-mail: joanna.kowalczyk@geo.uni.lodz.pl \\ 2 WSB University in Poznań \\ Institute of Social and Economic Sciences \\ e-mail: marek.nowacki@wsb.poznan.pl
}

\begin{tabular}{l|l} 
JEL CODES & I31, J11, R12, Z32, Z38
\end{tabular}

KEYWORDS generational cohort segmentation, urban tourism, post-industrial city

ABSTRACT Reflection on the contemporary character of tourist traffic in the city, in particular on the goals of visits and ways of spending time by visitors, shows new, currently emerging patterns of urban tourism. At the same time, many works on tourist demand, especially from the perspective of sociodemographic changes, stress differences between generations in their preferences and behaviour. Current research on urban tourism clearly lacks a transgenerational perspective, which would take into empirical consideration generational cohorts. The aim of the article is to establish the differences between generations of Poles engaging in urban tourism (in the context of a post-industrial city). Source material for the work comes from studies on tourist traffic in the city of Łódź conducted in 2009 and 2016; further generational segmentation has been based on these data.

\section{Introduction}

Urban tourism is nowadays considered to be one of the rapidly developing types of tourism, both in terms of the growth of the phenomenon, transformations of the tourist demand, and the broadly understood city offer. Academic reflection on the contemporary character of tourist traffic in the city, in particular on the goals of visits and ways of spending time, shows development of new patterns of tourist consumption of the city (Spirou, 2011). These changes are a part of a broader 
post-modernist socio-cultural transformation, in which tourism is a constitutive element inseparably connected with globalisation and development of the mass consumption industry. They are also related to post-industrial transformations of modern cities and, in particular, their inner cities, which are increasingly - in economic and social terms - influenced by tourism with commodification of leisure and culture (Gotham, 2018; Kowalczyk-Anioł, 2018; Kotus, Rzeszewski, Ewertowski, 2015; Spirou, 2011). As noted by Aleksandrova, Rogova and Sluka (2011), cities offer the best developed leisure infrastructure; Clark (2004), on the other hand, who sees cities as an "entertainment machine", stresses that culture, entertainment and urban amenities are becoming main drivers for modern urban policy and urban development (see also Kowalczyk, Derek, 2015). Ashworth and Page (2011, p. 4) noted that "leisure economies... shape new geographies of urban consumption and production." Attractiveness for tourism and leisure is one dimension of competition between cities, both on a global, national and on a regional scale. Apart from the image, the stakes include visitors (tourists, one day visitors, commuters, shoppers) and residents, who in practice increasingly often use the same space and urban offering, in particular entertainment/leisureoriented facilities. Moreover, as noted by Meyer and Niezgoda (2018, p. 51), "with the constant compression of leisure time, tourism activities in the visited locations become more similar to the leisure activities of residents."

In the modern, globalised world, cities are on one hand becoming more similar to one another thanks to implementation of similar projects and the same network shopping and gastronomy facilities; on the other hand, globalisation forces cities to select strategies of differentiation and encourages locally-based place identities (Hall, Williams, 2002; Zmyślony, 2016). Many of the changes observed in the urban space are a result of large revitalization projects, which in post-socialist cities, such as Łódź, cover in particular post-industrial areas located in the city centre, where entertainment, shopping and culture-related functions are introduced (e.g. Manufaktura - one of the main tourist attractions in Łódź), creating new tourist and leisure space (Mokras-Grabowska, 2018). At the same time, many European examples, in particular from the CEE region, show that the growth of the hospitality industry (including development of urban amenities, as underlined by Clark) can proceed without a plan and consist in the introduction of a new function in an old (sometimes dilapidated) structure (e.g. inner city of Budapest and the phenomenon of "ruin bars" - Smith et al., 2018).

Some works stress the perspective of socio-demographic changes and emphasise differences between generations as an important factor in the interpretation and differentiation of tourism preferences, behaviour and choice (Chen, Shoemaker, 2014; Kachniewska, 2014; MarkiewiczPatkowska, Pytel, Widawski, Oleśniewicz, 2018; Monaco, 2018; Pennington-Gray, Fridgen, Stynes, 2003; Sawińska, 2014; Seweryn, 2017; Zajadacz, 2014). As one of the most recent challenges, Corbisiero and Ruspini (2018) describe, among others, how the tourism industry should prepare for the generational shift.

A generation is the total of individuals born and living at the same time; it is also a community of experiences shaped by a specific society, because a common social and historical situation shapes similar attitudes, motivations, expectations and value systems (Wiktorowicz et al., 2016). 
Gardiner, Grace, King (2014) notice that the popularity of generational segmentation in tourism research stems from the fact that it provides better opportunities than those offered by demographic segmentation based on chronological age and life stage.

According to Ruspini and Melotti (2016), the generation whose needs have deeply transformed and are still transforming our contemporary cities is Generation Y (Millennials). They argue that "we are facing a multi-level, co-creative and often informally carried out urban planning where residents, tourists, policy-makers and other stakeholders are adapting the urban space to the needs of this generation" (p. 1). Veiga et al. (2017) pose a straightforward question: Will Ys change the character of global tourism? When answering this question, they focus on the behaviour of one age cohort. According to these authors, the growing importance of Generation Y (slowly passing the young adult phase) belongs to logical and natural order of things, however the structure of today's tourism consumption of the city is equally strongly influenced by the extremely numerous and consumption-oriented, aging generation of baby boomers (BB) who both around the world and in Poland have shaped the patterns of mass tourism (Kowalczyk-Anioł, 2013), and by Generation X who are currently in the adult phase.

The existing studies on preferences and tourist behaviour are dominated by the characteristics of one selected generation. There is, however, a lack of works which would verify the theses about the described differences from the perspective of transgenerational research, covering behaviour of visitors to the same city at the same time. This gap will be addressed in this article, against the background of the use of the tourist offer of a post-industrial city.

\section{Method}

The authors used data collected during studies of tourist traffic in Łódź in 2009 and 2016 (questionnaire method - standardised face-to-face interview - PAPI) as the source material for analysis of the phenomenon for the cohorts of Poles of the generations BB, X and Y. The results of the performed generational segmentation have been confronted with available observations from the literature. The study adopts the following time frames for generations: Baby Boomers (1943-1960), Generation X (1961-1979) and Generation Y (1980-2000). The study sample was $n=1430$ persons of which 603 persons were interviewed in 2009 and 827 - in 2016 (tab. 1). ${ }^{1}$ In 2009, 178 persons represented Generation Y, 311 - Generation X and 114 - BB. In 2016, the numbers were, respectively: $\mathrm{Y}-409, \mathrm{X}-353$ and $\mathrm{BB}-65$.

1 The analysis covered only Polish residents, who in the reported populations constituted respectively $81 \%$ (Liszewski, 2010) and 79.5\% (Kowalczyk-Anioł, 2017; Włodarczyk, 2017). 
Table 1. Characteristics of the sample

\begin{tabular}{|c|c|c|c|c|c|c|}
\hline & \multicolumn{3}{|c|}{2009} & \multicolumn{3}{|c|}{2016} \\
\hline & $\mathrm{Y}$ & $\mathrm{X}$ & $\mathrm{BB}$ & $\mathrm{Y}$ & $\mathrm{X}$ & $\mathrm{BB}$ \\
\hline Number & 178 & 311 & 114 & 409 & 353 & 65 \\
\hline \multicolumn{7}{|l|}{ Sex } \\
\hline Female & $91(51.1 \%)$ & $171(55.0 \%)$ & $50(43.8 \%)$ & $226(55.2 \%)$ & $192(54.3 \%)$ & $47(72.3 \%)$ \\
\hline Male & $87(48.9 \%)$ & $140(45.0 \%)$ & $64(56.1 \%)$ & $183(44.7 \%)$ & $161(45.6 \%)$ & $18(27.7 \%)$ \\
\hline \multicolumn{7}{|c|}{ Tourists/ One day visitors } \\
\hline Tourists & $80(44.9 \%)$ & $193(62.1 \%)$ & $70(61.4 \%)$ & $241(58.9 \%)$ & $211(59.8 \%)$ & $34(52.3 \%)$ \\
\hline $\begin{array}{l}\text { One day } \\
\text { visitors }\end{array}$ & $98(55.1 \%)$ & $118(37.9 \%)$ & $44(38.6 \%)$ & $168(41.1 \%)$ & $142(40.2 \%)$ & $31(47.7 \%)$ \\
\hline
\end{tabular}

Source: own study.

Analyses of relations between the variables were performed in the statistical package Statistica 12.0. Relationships between the cross-tabulated categorical variables were tested using Pearson Chi-square test. Differences between the cohorts in the level of quantitative interval variables (number of visits, nights) were calculated using one-way ANOVA analysis.

\section{Study resullts}

In the first phase of the analysis, differences between the cohorts owing to the characteristics of the trip were calculated (tab. 2). One-way ANOVA analysis revealed that significant differences between the number of visits to Łódź occurred between Generations $\mathrm{Y}$ and X in 2009 and Generation $\mathrm{X}$ in $2016(\mathrm{~F}=4.17 ; \mathrm{p}<0.001)$. There were no significant differences in the number of nights. There was, however, a significant increase in the intention to increase spending in 2016 by all cohorts, in particular among BBs, where the increase almost doubled.

Table 2. Traits of interviewed generations

\begin{tabular}{|l|c|c|c|c|c|c|c|}
\hline \multirow{2}{*}{ Traits of interviewees } & \multicolumn{3}{|c|}{2009} & \multicolumn{3}{|c|}{2016} & \multirow{2}{*}{$\mathrm{F}(\mathrm{p})$ or $\chi^{2}(\mathrm{p})$} \\
\cline { 2 - 8 } & $\mathrm{Y}$ & $\mathrm{X}$ & $\mathrm{BB}$ & $\mathrm{Y}$ & $\mathrm{X}$ & $\mathrm{BB}$ & \multirow{2}{*}{ (0.001) } \\
\hline Number of stays in Łódź before & 4.05 & 3.81 & 3.44 & 3.03 & 2.64 & 2.87 & $4.17(\mathbf{0 . 0 0 1}$ \\
\hline Number of nights spent in Łódź & 1.25 & 1.49 & 1.21 & 1.89 & 1.49 & 1.62 & $1.12(0.32)$ \\
\hline Intention to increase spending & $43.6 \%$ & $38.6 \%$ & $42.7 \%$ & $50.0 \%$ & $52.3 \%$ & $74.6 \%$ & $34.3(\mathbf{0 . 0 0 1})$ \\
\hline
\end{tabular}

Source: own study.

A comparison of the main declared purposes for visiting Łódź between the investigated cohorts shows changes which occurred in the studied period (tab. 3). In 2009, interviewees from Generation Y stated as the main purpose visiting friends and relatives (VFR) and events, $\mathrm{X}$ - business, while BBs - sightseeing and business. In 2016, Ys and Xs declared in the first place business and events with significant presence of VFR and, in the case of Ys, education. Generation BB, which in 2009 was most interested in sightseeing, started to come to Łódź for VFR, events and shopping. 
Table 3. Main declared purpose of visiting Łódź

\begin{tabular}{|c|c|c|c|c|c|c|}
\hline \multirow{2}{*}{ Purpose } & \multicolumn{3}{|c|}{2009} & \multicolumn{3}{|c|}{2016} \\
\hline & Y (\%) & X (\%) & BB (\%) & Y (\%) & X (\%) & BB (\%) \\
\hline Sightseeing & 5.6 & 4.2 & 17.5 & 2.2 & 2.9 & 7.7 \\
\hline Cultural or sport event & 14.6 & 7.4 & 10.5 & 22.0 & 18.8 & 7.7 \\
\hline Business & 1.1 & 18.3 & 15.8 & 20.2 & 36.3 & 3.6 \\
\hline Transit & 11.8 & 6.7 & 8.8 & 2.7 & 3.8 & 11.8 \\
\hline Education & 2.8 & 0.6 & 0.9 & 13.8 & 3.8 & 0.0 \\
\hline Shopping & 6.7 & 2.6 & 2.6 & 5.2 & 6.1 & 6.7 \\
\hline Leisure & 10.7 & 9.6 & 5.3 & 6.7 & 6.4 & 1.5 \\
\hline VFR & 15.2 & 8.7 & 7.9 & 13.1 & 10.1 & 18.5 \\
\hline Chi-square test & \multicolumn{6}{|c|}{$\chi^{2}=823.22 ; p<0.001$} \\
\hline
\end{tabular}

Please note: The table includes only one main purpose declared by each interviewee.

Source: own study.

In nearly all categories of ways of spending time in Łódź, the investigated cohorts differed between one another (tab. 4). Generation $\mathrm{Y}$ is significantly distinguished from the others by spending time in clubs and pubs. Over $1 / 3$ of persons of this generation (2016) spent time in restaurants and 1/5 - in cinemas. A clear decrease of interest in visits to museums is conspicuous in all cohorts: nearly two times fewer persons visited those in 2016 than in 2009. This pertains also to sightseeing in general. The situation is quite the reverse with respect to meeting friends: in all cohorts interest in this form of spending time increased, just like interest in events which nearly doubled.

Tahle 4. Way of spending time in Łódź by interviewees

\begin{tabular}{|l|c|c|c|c|c|c|c|}
\hline \multirow{2}{*}{ Way of spending time } & \multicolumn{3}{|c|}{2009} & \multicolumn{3}{|c|}{2016} & \multirow{2}{*}{$\begin{array}{c}\text { Chi-square test } \\
\chi^{2}(\mathrm{p})\end{array}$} \\
\cline { 2 - 8 } & $\mathrm{Y}(\%)$ & $\mathrm{X}(\%)$ & $\mathrm{BB}(\%)$ & $\mathrm{Y}(\%)$ & $\mathrm{X}(\%)$ & BB (\%) & $44.4(\mathbf{0 . 0 0 1})$ \\
\hline Leisure & 30.3 & 18.3 & 22.8 & 38.9 & 33.7 & 43.1 & $8.7(0.12)$ \\
\hline Walking & 74.2 & 75.9 & 71.0 & 68.2 & 75.3 & 66.1 & $65.2(\mathbf{0 . 0 0 1})$ \\
\hline Clubs, pubs & 23.0 & 15.4 & 4.4 & 20.8 & 5.4 & 3.1 & $29.9(\mathbf{0 . 0 0 1})$ \\
\hline Restaurants & 17.4 & 23.2 & 31.6 & 34.7 & 24.4 & 15.4 & $110.9(\mathbf{0 . 0 0 1})$ \\
\hline Cinemas & 7.8 & 2.6 & 2.6 & 23.7 & 9.9 & 0.0 & $15.5(\mathbf{0 . 0 0 8})$ \\
\hline Theaters & 3.4 & 1.6 & 3.5 & 7.6 & 5.1 & 6.1 & $48.4(\mathbf{0 . 0 0 1})$ \\
\hline Suseums & 21.9 & 17.7 & 21.0 & 10.0 & 5.9 & 4.6 & $38.3(\mathbf{0 . 0 0 1})$ \\
\hline Meeting friends & 41.6 & 39.2 & 54.4 & 29.8 & 27.5 & 33.8 & $49.5(\mathbf{0 . 0 0 1})$ \\
\hline Events & 32.6 & 20.3 & 13.2 & 37.9 & 24.1 & 35.4 & $54.2(\mathbf{0 . 0 0 1})$ \\
\hline Others & 18.5 & 20.3 & 18.4 & 35.2 & 38.2 & 27.7 & $28.9(\mathbf{0 . 0 0 1})$ \\
\hline
\end{tabular}

Please note: The table includes any number of ways of spending time in Łódź given by interviewees.

Source: own study.

Analysis of differences between the groups has also shown that in 2009 the analysed cohorts did not differ between each other with respect to the main source of information about Łódź. Such differences occurred in 2016 and between 2009 and 2016 the significance of traditional sources dropped significantly, with the Internet on the rise. Transgenerational differences are still visible: 
many more BBs (2016) still used the press, television and especially information from friends and families. For the Internet, the reverse is true: for only $15 \%$ of BBs Internet was the main source of information about Łódź. No significant differences between the generations were recorded in the evaluation of the city: all of them rated the highest the atmosphere, hospitality and kindness of inhabitants and noted significant improvement to the night stay offering as well as aesthetics of the city. The younger generations appreciated more the development of entertainment and urban amenities, while BBs rated the worst discos, pubs and clubs, i.e. youth-oriented entertainment facilities.

\section{Discussion and results}

Our findings show that there are clear differences in the tourist consumption of the city between the generations. Moreover, the dynamic approach to the behaviour of the generations confirms certain directions of change, observable with age, also within generations (in particular the growing Y). Generation Y most often comes to Łódź for events, in the company of friends, to friends and spends leisure time together with them, even when they more often travel for business. In contrast, BBs travel with families and appear to be more willing to increase their spending. Generation X more often than the others travel nowadays for business-related purposes, but in their leisure time they participate most frequently in events in Łódź. The results also show that BBs still appear to be more interested in traditional sightseeing than the younger generations. This result is consistent with the previous research (Huang, Petrick, 2009; Lebrun, 2014; Pennington-Gray, Fridgen, Stynes, 2003) showing that this generation is more attracted than Generation $\mathrm{X}$ by historical and architectural aspects of cities. At the same time, the younger generations $-\mathrm{X}$ and $\mathrm{Y}-$ are more interested in gastronomy than the Baby Boomers. This is consistent with Lebrun's (2014) findings about Generation X and works focused on and describing Generation Y (Corbisiero, Ruspini, 2018; Kowalczyk-Anioł, 2012). Generation Y makes more use of amenities of Łódź - pubs and clubs, starting with cinemas, theatres and ending with museums. On the other hand, shopping, which is one of the biggest urban tourism activities, shows no difference between the analysed generations, as pointed out by Pennington-Gray et al. (2003) and Lebrun (2014). Generations Y and X (which is most often discussed in the literature) are more ICT-oriented in their search of a source of information about the city, however all the generations place a high value (BBs the highest) on information from friends and family.

The findings shed more light on the transformation of the tourist traffic in Łódź, as described by Kowalczyk-Anioł (2015) and Matczak (2017), which is a post-industrial city, creating its tourist offer primarily using central, revitalised urban space, the attributes of which in particular for younger generations are urban entertainment and leisure amenities located therein. The diversity of purposes for visiting and ways of spending leisure time by visitors observed confirms the existence of a mosaic of drivers - described in the literature and typical of contemporary urban tourism - encompassing entertainment, shopping, business meetings, VFR and sightseeing (Ashworth, Page, 2011). The patterns of tourist consumption of the city focused on, among others, VFR, which 
are currently gaining ground, increasingly often result from the growing mobility of societies ${ }^{2}$ and the growing diversity and availability of the urban offering. At the same time, they show a growing convergence between local and tourist consumption (Ashworth, 2009). This is related to the sociocultural modernisation in which "consumerism is now ensconced as a cultural form" (Ashworth, Page, 2011, p. 6), while tourism and leisure have become a major element of lifestyle (Hołowiecka, Grzelak-Kostulska, 2013). This is also confirmed, in spite of the existing differences in the preferences and behaviour between generations of Poles visiting Łódź, by the results of the conducted analysis.

The research conducted has its limitations resulting from the character of the available data as well as the adopted generational cohort segmentation. At the same time, the exploration-oriented character of the research helps to outline directions for further search - including with the use of generational segmentation and determination of the consequences and challenges that the described phenomenon has for Polish cities, which increasingly often seek to use tourism development as a scenario for partial restructuring of the urban economy.

\section{References}

Aleksandrova, A., Rogova, S., Sluka, N. (2011). Miasta globalne w systemie ośrodków turystyki międzynarodowej, In: B. Włodarczyk (ed.), Turystyka (pp. 137-152). Łódź: Wydawnictwo Uniwersytetu Łódzkiego.

Ashworth, G. (2009). Questioning the urban in urban tourism. In: G. Maciocco, S. Serreli (eds.), Enhancing the City (pp. 207-220). Dordrecht: Springer.

Ashworth, G., Page, S. J. (2011). Urban tourism research: recent progress and current paradoxes. Tourism Management, 1 (32), 1-15.

Chen, S.C., Shoemaker, S. (2014). Age and Cohort Effects: The American Senior Tourism Market. Annals of Tourism Research, 48, 58-75.

Clark, T.N. (2004). The City as an Entertainment Machine. Research in Urban Policy. Oxford: Elsevier.

Corbisiero, F., Ruspini, E. (2018). Special Issue: Millennials and Generation Z: Challenges and Future Perspectives for International Tourism. Journal of Tourism Futures, 1 (4), 3-104.

Gardiner, S., Grace, D., King, C. (2014). The Generation Effect: The Future of Domestic Tourism in Australia. Journal of Travel Research, 6 (53), 705-720.

Gotham, K. (2018). Assessing and Advancing Research on Tourism Gentrification. Via. Tourism Review, 13. DOI: $10.4000 /$ viatourism.2169.

Hall, C.M., Williams, A. (2002). Tourism and Migration: New Relationships Between Production and Consumption. London: Kluwer Academic.

Hołowiecka, B., Grzelak-Kostulska, E. (2013). Turystyka i aktywny wypoczynek jako element stylu życia seniorów. Acta Universitatis Lodziensis Folia Oeconomica, 291, 163-179.

Huang, Y., Petrick, J. F. (2009). Generation Y's Travel Behaviours: A Comparison with Baby Boomers and Generation X. In: P. Bakendorff, G. Moscardo, D. Pendergast (eds.), Tourism and generation, (pp. 27-37). Oxfordshire: CABI.

Kachniewska, M. (2014). Pokolenie Y jako czynnik przeobrażeń rynku turystycznego. In: Z. Kruczek, W. Banasik (eds.), Dynamika przemian rynku turystycznego (pp. 7-19). Warsaw: Wyższa Szkoła Turystyki i Języków Obcych.

Kotus, J., Rzeszewski, M., Ewertowski, W. (2015). Tourists in the Spatial Structures of a Big Polish City: Development of an Uncontrolled Patchwork or Concentric Spheres? Tourism Management, 50, 98-110.

2 Major importance of VFR among tourists in Łódź is stimulated by employment-related mobility of its former inhabitants in the EU (GB, in particular) - Kowalczyk-Anioł (2015). 
Kowalczyk, A., Derek, M. (2015). Przestrzeń czasu wolnego w polityce dużych miast. Ruch Prawniczy, Ekonomiczny i Socjologiczny, 1 (77), 311-325.

Kowalczyk-Anioł, J. (2012). Tourism Trends among Generation Y in Poland. Tourism, 2 (22), 15-20.

Kowalczyk-Anioł, J., (2013). Różnice pokoleniowe w turystyce polskich seniorów - baby boomers versus pokolenie przedwojenne. In: R. Pawlusiński (ed.), Współczesne uwarunkowania i problemy rozwoju turystyki (pp. 135-149). Cracow: Instytut Geografii i Gospodarki Przestrzennej Uniwersytetu Jagiellońskiego.

Kowalczyk-Anioł, J. (2015). Tourism Development in Łódź in 2000-2014: Directions and Character of Change. Tourism, 2 (25), 107-115.

Kowalczyk-Anioł, J. (2017). Analiza ruchu turystycznego w Łodzi w świetle badań ankietowych. In: B. Włodarczyk (ed.), Ruch turystyczny w Łodzi i województwie łódzkim w 2016 roku (pp. 43-70). Łódź: Instytut Geografii Miast i Turyzmu.

Kowalczyk-Anioł, J. (2018). Koncepcja gentryfikacji turystycznej i jej współczesne rozumienie. Prace Geograficzne, 154, $35-54$.

Lebrun, A.M. (2014). Representations of a Destination City Break. Analysis Based on Free Associations. Journal of Travel \& Tourism Marketing, 2 (31), 195-210.

Liszewski, S. (ed.) (2010). Ruch turystyczny w Łodzi i województwie łódzkim w 2009 roku. Łódź: Łódzkie Towarzystwo Naukowe.

Matczak, A. (2017). Turystyka w strukturze funkcjonalnej dużego miasta. Przykład Łodzi. Acta Universitatis Lodziensis. Folia Geographica Socio-Oeconomica, 27, 127-139.

Markiewicz-Patkowska, J., Pytel, S., Widawski, K., Oleśniewicz, P. (2018). Turystyka senioralna w kontekście sytuacji materialnej polskich emerytów. Ekonomiczne Problemy Turystyki, 2 (42), 99-106.

Meyer, B., Niezgoda, A. (2018). The Impact of the Perception of Leisure on Recreational and Tourism Spaces in an Urban Area. Tourism, 1 (28), 47-52.

Mokras-Grabowska, J. (2018). New Urban Recreational Spaces. Attractiveness, Infrastructure Arrangements, Identity. The Example of the City of Łódź. Miscellanea Geographica, 4 (22), 219-224.

Monaco, S. (2018). Tourism and the New Generations: Emerging Trends and Social Implications in Italy. Journal of Tourism Futures, 1 (4), 7-15.

Pennington-Gray, L., Fridgen, J.D., Stynes, D. (2003). Cohort Segmentation: An Application to Tourism. Leisure Sciences, 25, 341-361.

Ruspini, E., Melotti, M. (2016). How is the Millennial Generation Reshaping Cities and Urban Tourism. Conference: Urban Planning and Tourism Consumption. Hebrew University of Jerusalem.

Sawińska, A. (2014). Seniorzy i preseniorzy jako perspektywiczny podmiot rynku turystycznego i rekreacyjnego. Rozprawy Naukowe Akademii Wychowania Fizycznego we Wroctawiu, 46, 171-177.

Seweryn, R. (2017). Pokolenie Baby Boomers na rynku turystycznym na przykładzie odwiedzających Kraków. Marketing i Zarządzanie, 2 (48), 105-116.

Smith, M.K., Egedy, T., Csizmady, A., Jancsik, A., Olt, G., Michalkó, G. (2018). Non-planning and Tourism Consumption in Budapest's Inner City. Tourism Geographies, 3 (20), 524-548.

Spirou, C. (2011). Urban tourism and urban change: Cities in a global economy. New York: Routledge.

Veiga, C., Águas, P., Custódio Santos, M., Santos, J.A.C. (2017). Are Millennials Transforming Global Tourism? Challenges for Destinations and Companies. Worldwide Hospitality and Tourism Themes, 6 (9), 603-616.

Wiktorowicz, J., Staszewska, E., Kuba, M., Warwas, I., Woszczyk, P., Stankiewicz, A., Kliombka-Jarzyna, J. (2016). Pokolenia - co się zmienia? Kompendium zarządzania multigeneracyjnego. Warsaw: Wolters Kluwer.

Zajadacz, A. (2014). Pokolenie X, Y, Z a fenomen turystyki. In: J. Śledzińska, B. Włodarczyk (eds.), Międzypokoleniowe aspekty turystyki (pp. 55-67), Warsaw: Polskie Towarzystwo Turystyczno-Krajoznawcze „Kraj”.

Zmyślony, P. (2016). Global Challenges, Local Sensitivities: Towards Internationalization of City Tourism Management. Current Issues of Tourism Research, 1 (5), 30-37. 


\section{KONSUMPCJA TURYSTYCZNA WSPÓŁCZESNEGO MIASTA - ANALIZA MIĘDZYPOKOLENIOWA}

\author{
SŁOWA KLUCZOWE \\ STRESZCZENIE
}

segmentacja pokoleniowa, turystyka miejska, miasto postindustrialne

Refleksja nad współczesnym charakterem ruchu turystycznego w mieście, zwłaszcza celami przyjazdu do miasta oraz sposobami spędzania czasu przez osoby je odwiedzające, pokazuje kształtujące się nowe wzorce turystyki miejskiej. Jednocześnie wiele prac na temat popytu turystycznego, zwłaszcza w perspektywie przemian społeczno-demograficznych, akcentuje różnice między pokoleniami w preferencjach i zachowaniach turystycznych. W dotychczasowych badaniach nad turystyką miejską wyraźnie brakuje perspektywy międzygeneracyjnej uwzględniającej empirycznie kohorty pokoleniowe. Celem artykułu jest określenie różnic między pokoleniami Polaków w turystyce miejskiej (w kontekście miasta poprzemysłowego). Materiał źródłowy pracy stanowią wyniki badań ruchu turystycznego w Łodzi prowadzonych w 2009 i 2016 roku, na których oparto dalszą segmentację pokoleniową. 